\title{
PERAN THEORY OF PLANNED BEHAVIOR DAN NILAI KEARIFAN LOKAL TERHADAP KEPATUHAN WAJIB PAJAK: SEBUAH KAJIAN EKSPERIMEN
}

\author{
I Nyoman Putra Yasa \\ putrayasainym@undiksha.ac.id \\ I Putu Hendra Martadinata \\ I Gede Putu Banu Astawa \\ Universitas Pendidikan Ganesha
}

\begin{abstract}
Tax compliance is one of the issues that is widely discussed in behavioral studies. According to researchers' knowledge, current research largely examines the intention of taxpayers' compliance, and research on taxpayers' compliance behavior is still limited. Therefore, this study aims to examine the taxpayers' compliance behavior by using one of the elements of Theory of Planned Behavior, namely perceived behavioral control, and local wisdom values, namely Tri Kaya Parisudha. This study used an experimental method with a total sample of 68 taxpayers. Based on the analysis using ANOVA, this study found that there is an interaction between perceived behavioral control and Tri Kaya Parisudha in influencing the taxpayers' compliance behavior. The application of the values of Tri Kaya Parisudha and the role of tax authorities in shaping the taxpayers' perceived behavioral control can increase taxpayers' compliance to pay taxes. The results of this study are expected to strengthen the relevance of Theory of Planned Behavior in explaining the taxpayers' compliance behavior without overlooking the aspects of local wisdom.
\end{abstract}

Key words: theory of planned behavior, perceived behavioral control, tri kaya parisudha, taxpayers' compliance behavior

\begin{abstract}
ABSTRAK
Kepatuhan pajak adalah salah satu masalah yang banyak dibahas dalam studi perilaku. Menurut pengetahuan peneliti, penelitian saat ini sebagian besar meneliti niat kepatuhan wajib pajak, dan penelitian tentang perilaku kepatuhan wajib pajak masih terbatas. Oleh karena itu, penelitian ini bertujuan untuk menguji perilaku kepatuhan wajib pajak dengan menggunakan salah satu elemen dari Theory of Planned Behavior, yaitu kontrol perilaku yang dirasakan, dan nilai-nilai kearifan lokal, yaitu Tri Kaya Parisudha. Penelitian ini menggunakan metode eksperimen dengan jumlah sampel sebanyak 68 wajib pajak. Berdasarkan analisis menggunakan ANOVA, penelitian ini menemukan bahwa ada interaksi antara kontrol perilaku yang dirasakan dan Tri Kaya Parisudha dalam mempengaruhi perilaku kepatuhan wajib pajak. Penerapan nilai-nilai Tri Kaya Parisudha dan peran otoritas pajak dalam membentuk kontrol perilaku yang dipersepsikan wajib pajak dapat meningkatkan kepatuhan wajib pajak untuk membayar pajak. Hasil penelitian ini diharapkan dapat memperkuat relevansi Theory of Planned Behavior dalam menjelaskan perilaku kepatuhan wajib pajak tanpa mengabaikan aspek kearifan lokal.
\end{abstract}

Kata kunci: teori perilaku terencana; kontrol perilaku persepsian; tri kaya parisudha; perilaku kepatuhan wajib pajak.

\section{PENDAHULUAN}

Bagi Indonesia, pajak merupakan sumber penerimaan terbesar dalam struktur Anggaran Penerimaan dan Belanja Negara
(APBN). Setiap tahun pajak selalu menjadi andalan bagi pemerintah dalam membiayai segala macam pengeluaran rutin dan kegiatan pembangunan negara (Putri dan 
Fanani, 2018). Dalam postur APBN 2019 seperti dikutip dari https://www.kemenkeu. go.id tanggal 6 Februari 2018 jumlah penerimaan negara adalah sebesar Rp. 2.143 triliun dengan penerimaan dari sektor perpajakan sebesar Rp. 1.781 triliun atau sebesar $83,11 \%$. Mengingat besarnya penerimaan dari sektor perpajakan, kepatuhan wajib pajak sangat diperlukan untuk dapat mencapai penerimaan sektor perpajakan tersebut (Yasa dan Prayudi, 2017).

Sejak diterapkannya self assessment system pada tahun 1983 peningkatan kepatuhan wajib pajak terus dilakukan oleh pemerintah sebagai akibat dari rendahnya kepatuhan wajib pajak di Indonesia (Damayanti et al., 2015). Rendahnya kepatuhan wajib pajak dapat dilihat dari tax ratio. Seperti yang dikutip dari https://www/ pajak.go.id tanggal 6 Februari 2019 tax ratio di Indonesia dari tahun 2015 sampai dengan tahun 2017 selalu mengalami penurunan. Pada tahun 2015 tax ratio Indonesia adalah sebesar 11,6\% dan tahun 2016 serta 2017 berturut-turut adalah sebesar $10,8 \%$ dan kembali mengalami penurunan menjadi 10,7\%. Menurut data Badan Pusat Statistik yang dikutip dari https://www.bps.go.id, khusus untuk pajak penghasilan yang dikenakan pada wajib pajak orang pribadi, telah terjadi penurunan penerimaan pajak dari tahun 2016 ke tahun 2017, yaitu sebesar Rp 657.162,70 milyar pada tahun 2016 menjadi Rp 637.859,30 milyar pada tahun 2017. Adanya penurunan ini diantaranya disebabkan oleh ketidakpatuhan wajib pajak. Oktaviani dan Nurhayati (2015) menyatakan bahwa salah satu ketidakpatuhan wajib pajak adalah seringkali tidak melaporkan atau mencantumkan pajak penghasilannya.

Namun yang menarik adalah pada tahun 2018 dimana tax ratio Indonesia mengalami peningkatan. Masih dikutip dari https://www/pajak.go.id tanggal 6 Februari 2019 tax ratio di Indonesia pada tahun 2018 adalah sebesar $11,5 \%$ mengalami peningkatan $0,8 \%$ dari tahun 2017 . Selain tax ratio, penerimaan pajak pada tahun 2018 juga mengalami peningkatan dari tahun 2017. Berdasarkan keterangan pers Kementerian Keuangan No. 1/KLI/ 2019 tanggal 2 Januari 2019 yang dikutip melalui $h t t p s: / / w w w$. ortax.org tanggal 6 Februari 2019, penerimaan pajak tahun 2018 adalah sebesar Rp. $1.521,4$ triliun atau sebesar $94 \%$ dari target. Hal ini mengalami peningkatan dari tahun 2017 yang hanya $91 \%$ dari target atau sebesar Rp. 1.331 triliun. Selain secara nasional, peningkatan penerimaan pajak juga terjadi di beberapa Kantor Wilayah DJP yang membawahi Kantor Pelayanan Pajak di daerah. Salah satunya adalah di Bali. Dikutip dari https://bali.tribunnews.com tanggal 6 Februari 2019, realisasi penerimaan sampai dengan 12 Desember 2018 mengalami pertumbuhan sebesar 16,03\% dari tahun 2017. Selain itu, dari sisi kepatuhan telah mencapai $90 \%$.

Terkait dengan kepatuhan, telah menjadi isu oleh para peneliti dari berbagai belahan dunia. Damayanti et al. (2015) berpendapat bahwa lebih baik mengeksporasi pendekatan diluar ekonomi untuk memahami faktor-faktor non ekonomi yang mempengaruhi perilaku dalam membayar pajak. Kepatuhan wajib pajak yang dahulu lebih fokus pada aspek ekonomi, saat ini telah bergeser pada pendekatan sosial psikologi dengan pendekatan non ekonomi. Maka dari itu, dibutuhkan pendekatan psikologis dalam menjelaskan perbedaan perilaku kepatuhan wajib pajak. Salah satu teori yang menjelaskan aspek psikologi dan perilaku seseorang adalah Theory of Planned Behaviour (TPB). TPB menyatakan bahwa sikap akan mempengaruhi perilaku melalui proses pengambilan keputusan dan direncanakan, sehingga individu akan melakukan tindakan tertentu ketika hal tersebut dipandang positif, percaya individu lain ingin dia melakukannya dan percaya dia bisa melakukannya (Damayanti et al., 2015).

Secara umum, penelitian ini bertujuan untuk menguji perilaku kepatuhan perpajakan wajib pajak di wilayah Provinsi Bali atas peningkatan kepatuhan yang terjadi dalam kerangka TPB. Sejauh pengetahuan peneliti, penelitian kepatuhan wajib pajak 
sebagian besar masih berkaitan pada niat wajib pajak, sedangkan penelitian yang berkaitan dengan perilaku wajib pajak masih terbatas. Oleh karena penelitian ini menguji perilaku, maka unsur TPB yang digunakan sebagai variabel dalam penelitian ini adalah kontrol perilaku yang dirasakan individu (perceived behavioral control). Hal tersebut didasari atas perceived behavioral control yang merupakan komponen yang terpenting dalam memprediksi perilaku nyata individu dalam konteks TPB (López-Mosquera, 2016).

Selain TPB, penelitian kali ini juga mengajukan konsep etika berbasis ajaran Tri Kaya Parisudha (TKP) - tiga gerak perbuatan dan tingkah laku manusia yang harus disucikan, yaitu berfikir, berkata dan berbuat yang baik. TKP merupakan salah satu kearifan lokal masyarakat Bali yang menjadi acuan berperilaku dalam kehidupan seharihari (Kepramareni et al., 2014; Swardhana et al., 2015; Yasa dan Prayudi, 2017). Pemilihan TKP ini berdasarkan penelitian Marandu et al. (2015) yang menyarankan pengembangan penelitian kepatuhan wajib pajak berdasarkan TPB. Marandu et al. (2015) menyatakan bahwa TPB merupakan teori yang bersifat umum, sehingga TPB berkemungkinan gagal untuk menjelaskan perilaku wajib pajak yang memiliki karakteristik unik tertentu. Kearifan lokal, dalam hal ini adalah Tri Kaya Parisudha, merupakan salah satu karakteristik unik yang dimiliki oleh masyarakat Bali, sehingga penelitian ini mengajukan TKP untuk mengembangkan kajian mengenai perilaku kepatuhan wajib pajak.

Penelitian ini secara keseluruhan bertujuan untuk menguji pengaruh kombinasian antara TPB dan nilai kearifan lokal (TKP) terhadap perilaku kepatuhan wajib pajak. Untuk itu, penelitian ini menggunakan metode eksperimen untuk melihat lebih mendalam interaksi kombinasian antar variabel tersebut. Penelitian kali ini diharapkan dapat memberi kontribusi secara teoritis berupa sumbangsih pemikiran pada bidang Akuntansi dan Perpajakan terkait kepatuhan wajib pajak dalam memenuhi kewajiban perpajakannya. Melalui pertimbangan atas pengaruh aspek etika berbasis kearifan lokal terhadap perilaku kepatuhan perpajakan, hasil penelitian juga diharapkan dapat berkontribusi pada pengembangan teori-teori keperilakuan sehubungan dengan peran faktor-faktor non-ekonomi sebagai anteseden perilaku individu. Secara praktis, temuan-temuan dalam penelitian kali ini diharapkan dapat menjadi input bagi para penyusun kebijakan dalam rangka meningkatkan kepatuhan wajib pajak demi memaksimalkan besaran penerimaan negara.

\section{TINJAUAN TEORETIS \\ Tri Kaya Parisudha}

Berdasarkan ajaran Agama Hindu, manusia memiliki kewajiban untuk taat terhadap ajaran dan nilai-nilai berlandaskan dharma atau kebenaran. Kewajiban manusia untuk melaksanakan ajaran serta aspekaspek yang terkandung dalam ajaran agama dalam Hindu disebut dengan dharma agama (Kiriana, 2017). Dengan kata lain, dharma agama merupakan salah satu kewajiban manusia, dalam hal ini adalah kewajiban untuk menerapkan nilai-nilai religius dalam kehidupan sehari-hari. Salah satu nilai religius yang dapat diterapkan adalah Tri Kaya Parisudha.

Tri Kaya Parisudha merupakan salah satu nilai keagamaan yang telah menjadi kearifan lokal masyarakat Bali, dan dapat dijadikan sebagai pedoman hidup manusia dengan tujuan untuk mencapai keharmonisan di dalam kehidupan ini. Tri Kaya Parisudha berasal dari kata tri yang memiliki arti tiga, kaya yang memiliki arti perbuatan, dan parisudha yang memiliki arti penyucian (Rosalina, 2017). Sehingga secara keseluruhan, Tri Kaya Parisudha merupakan tiga perbuatan atau tingkah laku yang harus disucikan (Rosalina, 2017). Tri Kaya Parisudha menjadi sebuah pedoman etika bagi umat Hindu di Bali melalui penyucian tiga unsur dalam berperilaku, yaitu pikiran (manacika), perkataan (wacika) dan perbuatan (kayika). Konsep manacika merupakan kosep yang didasarkan pada pikiran yang benar dan suci didasarkan pada ajaran agama Hindu. 
Konsep manacika dalam Tri Kaya Parisudha menempati posisi yang penting, karena manacika akan mempengaruhi perkataan (wacika) dan perbuatan (kayika). Pikiran yang dilandasi oleh dharma akan menggerakkan perkataan yang sesuai dengan ajaran dharma, demikian juga perbuatan yang akan mencerminkan pikiran yang suci. Jadi pada dasarnya perkataan dan perbuatan manusia tersebut bersumber dari pikiran. Pikiran yang baik akan menuntun manusia berkata atau berbuat yang baik pula (Widyani, 2015). Itulah sebabnya, mengapa manusia perlu menjaga pikirannya, mengatur pikirannya, mengendalikan pikirannya dengan baik, sebagaimana ditegaskan dalam Kitab Manawa Dharmasastra berikut ini:

Sloka IV - 18

Wayasah karmano' rthasya

Srutasyabhijanasya ca

Wesawag buddhi sarupyam

Acaran wicaredika

Artinya: Berjalan di dunia ini hendaknya menyesuaikan. Pakaian, kata-kata serta pikirannya agar sesuai dengan kedudukan dan kekayaannya. Sesuai pelajaran suci dan kewangsaannya.

Sloka XII - 3

Subhasubha phalam karma

Manowagdeha sambhawam

Karmaja gatayo nrnam

Uttama dhyamah

Artinya: Karma yang lahir dari pikiran, perkataan dan perbuatan menimbulkan akibat baik atau buruk dengan karma yang telah menyebabkan timbulnya berbagai keadaan pada diri manusia.

Konsep wacika merupakan konsep yang didasarkan perkataan yang baik, jujur, dan tidak menyinggung orang lain. Tri Kaya Parisudha mewajibkan manusia untuk selalu mengendalikan perkataan yang diucapkan agar selalu berlandaskan dengan ajaran dharma. Sedangkan konsep kayika merupakan konsep yang menuntut manusia untuk selalu berbuat (berperilaku) berdasarkan pada ajaran dharma. Manusia dituntut agar selalu berbuat dan perperilaku agar dapat membawa dampak positif, baik bagi dirinya maupun bagi orang lain. Menurut sumber yang lain yaitu Kitab suci Sarasamuscaya, Tri Kaya Parisudha merupakan salah satu ajaran etika yang memuat sepuluh perilaku yang perlu dikendalikan atau disucikan, yaitu tiga pengendalian pikiran yang harus disucikan, empat perkataan yang perlu dikendalikan, dan tiga perbuatan yang perlu disucikan dan dikendalikan. Secara ringkas diuraikan sebagai berikut: a) berpikir yang bersih dan suci (tidak memiliki keinginan dan tidak dengki terhadap milik orang lain, tidak berpikir buruk terhadap orang lain dan kepada semua mahkluk, dan tidak mengingkari hukum karmapala atau kasualitas dalam kehidupan), b)berkata yang baik atau suci dan benar (tidak berkata jahat, tidak berkata kasar, tidak memfitnah, dan tidak berkata yang mengandung kebohongan), dan c) berbuat yang baik atau suci (tidak menyakiti, menyiksa, apalagi membunuh mahkluk lain, tidak berbuat curang, sehingga berakibat merugikan orang lain, tidak berzinah atau tidak melakukan perbuatan yang serupa) (Adnyana dan Citrawathi, 2017).

Dengan pemahaman yang mendalam tentang konsep ajaran Tri Kaya Parisudha diharapkan memunculkan karakter baik (good character) yang merupakan inti dari ajaran Tri Kaya Parisudha yang terdiri dari berpikir baik (Manacika), berkata baik (Wacika) dan berbuat yang baik (Kayika), sebab karakter yang baik akan melibatkan pengetahuan moral (moral knowing), perasaan moral (moral feeling) dan tindakan moral (moral acting) (Adnyana dan Citrawathi, 2017).

Dengan adanya pemahaman serta penerapan konsep Tri kaya Parisudha akan dapat meningkatkan tingkat ketaatan dan kesadaran seseorang pada ajaran agamanya (moralitas) yang pada akhirnya akan meningkatkan dan mampu menjadikan seseorang tersebut menjadi pribadi yang memiliki karakter yang baik (good character) sesuai dengan ajaran agama (religius) baik sebagai pribadi maupun sebagai warga negara yang baik. Sebagai warga negara 
karakter yang baik (good character) dapat ditunjukan atau diwujudkan dengan memacu perilaku positif dan mencegah perilaku negatif terhadap kepatuhan perpajakan sehingga mendorong peningkatan kepatuhan wajib pajak. Patuh untuk membayar pajak merupakan salah satu kewajiban manusia terhadap negara, yang dalam ajaran Hindu disebut dengan dharma negara (Kiriana,
2017). Dengan begitu, pemenuhan kewajiban warga negara terhadap negaranya (dharma negara), dalam hal ini adalah membayar pajak, dapat didorong melalui pemahaman dan penerapan nilai-nilai agama (dharma agama) oleh para wajib pajak.

Hubungan antara Tri Kaya Parisudha dan kepatuhan wajib pajak dapat dilihat pada Gambar 1.

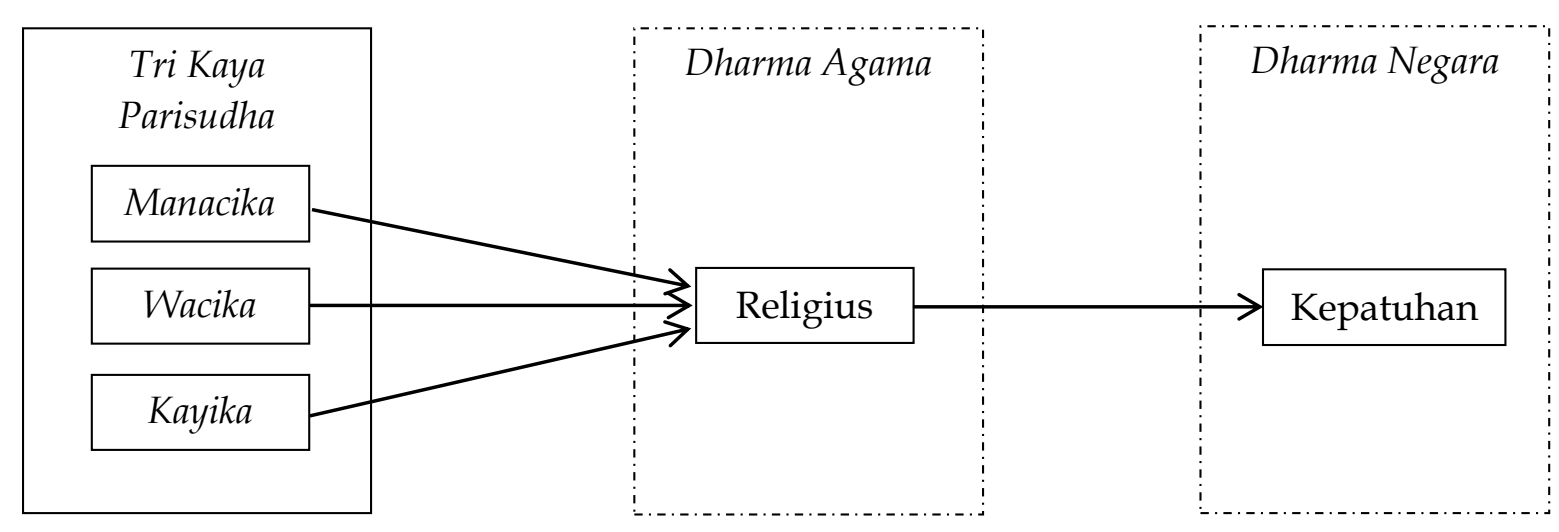

Gambar 1

Hubungan Antara Tri Kaya Parisudha dan Kepatuhan Wajib Pajak

Hubungan konsep kepatuhan sebagai wajib pajak apabila dilihat dari konsep agama Hindu dapat menggunakan pendekatan konsep ajaran Tri Kaya Parisudha yang merupakan landasan etika dalam agama Hindu. Sehingga dapat dikatakan bahwa konsep Tri Kaya Parisudha sangat potensial untuk meningkatkan niat dan kepatuhan dari wajib pajak untuk melaksana kan kewajiban pajaknya (membayar).

\section{Theory of Planned Behavior}

Salah satu teori yang popular dalam menjelaskan perilaku adalah teori perilaku terencana (theory of planned behavior-TPB). Di dalam teori perilaku terencana, dijelaskan bahwa faktor utama yang menyebabkan munculnya perilaku individu adalah niat untuk melakukan perilaku tersebut (Novianti dan Dewi, 2018). Teori perilaku terencana memaparkan tiga komponen yang dapat mempengaruhi timbulnya suatu niat, yang kemudian akan berkontribusi pada terbentuknya perilaku individu. Ketiga komponen tersebut merupakan sikap (attitudes), norma subjektif (subjective norms), dan kontrol perilaku yang dirasakan (perceived behavioral control) (Novianti dan Dewi, 2018). Secara keseluruhan, niat memediasi hubungan antara tiga komponen TPB (sikap, norma subjektif dan kontrol perilaku yang dirasakan) dengan perilaku individu (Kautonen et al., 2015).

Gambar 2 merupakan gambaran teori perilaku terencana dalam aspek kepatuhan wajib pajak. Sikap terhadap perilaku (attitudes toward behavior) merupakan penilaian individu terhadap suatu perilaku berdasarkan pertimbangan dampak positif maupun negatif yang akan ditimbulkan dari perilaku yang akan dilakukan (Nurwanah et al., 2018). Suatu niat akan timbul apabila individu merasa bahwa perilaku yang akan dilaksana kan membawa manfaat atau keuntungan bagi dirinya. Dengan pandangan tersebut, individu akan semakin terdorong untuk mewujudkan niatnya dengan berperilaku secara nyata. Sebaliknya, niat akan semakin 
menurun apabila individu menilai bahwa perilaku yang akan dilaksanakan membawa kerugian bagi dirinya, sehingga individu enggan untuk mewujudkan niatnya.

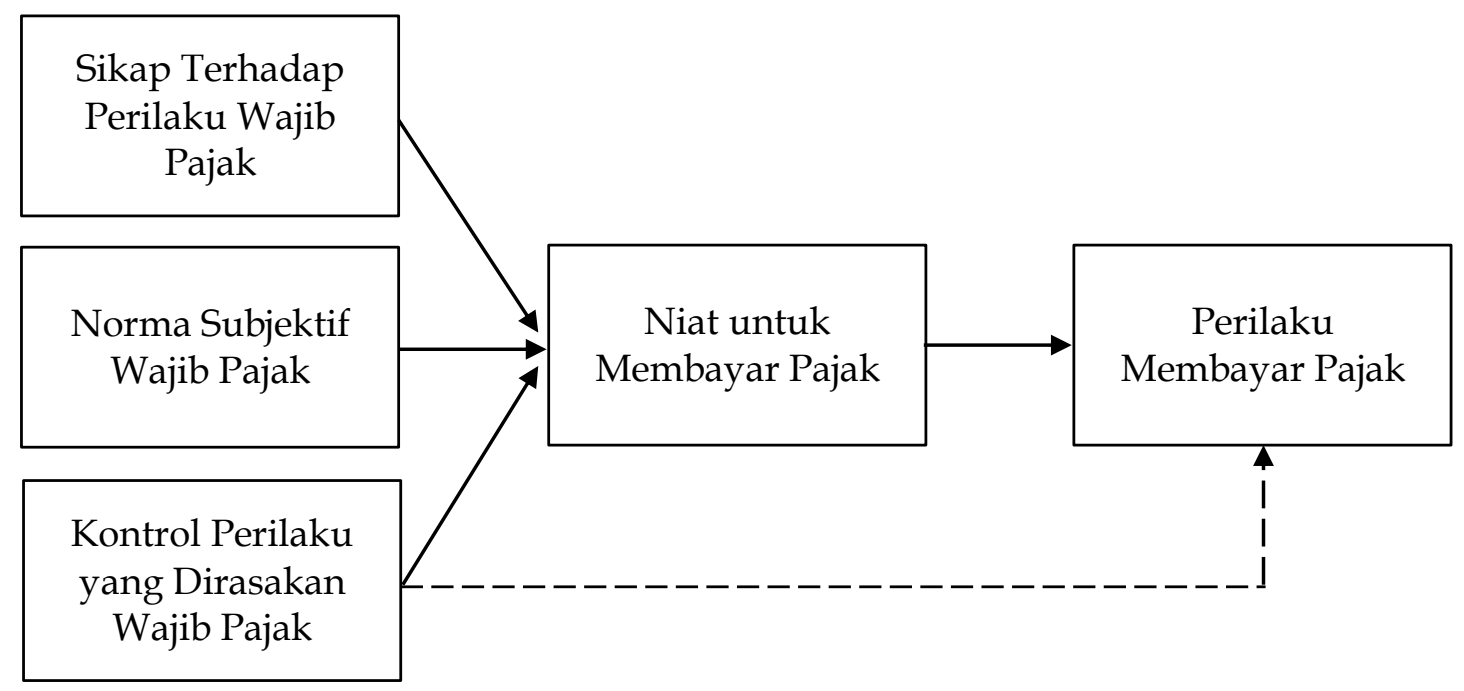

Gambar 2

Teori Perilaku Terencana dalam aspek Kepatuhan Wajib Pajak

Apabila dikaitkan dengan konteks kepatuhan wajib pajak, wajib pajak akan memiliki niat untuk membayar pajak apabila merasa bahwa membayar pajak akan menimbulkan dampak positif, baik kepada dirinya maupun lingkungan sekitarnya. Sebaliknya, niat untuk membayar pajak akan rendah apabila wajib pajak merasa bahwa membayar pajak tidak akan membawa dampak positif, baik bagi dirinya maupun lingkungan sekitarnya.

Norma subjektif (subjective norms) merupakan norma subjektif merupakan norma yang dianut oleh individu dengan merujuk pada norma lingkungan sekitarnya (Onu dan Oats, 2015). Selain itu, norma subjektif dapat dipandang sebagai tekanan sosial yang mempengaruhi individu dalam melakukan suatu tindakan (Nurwanah et al., 2018). Berbagai macam studi telah menemukan bahwa lingkungan sosial dapat menekan dan memaksa individu untuk melakukan suatu tindakan. Hal tersebut disebabkan oleh adanya ketakutan dari individu terhadap penilaian sosial yang diberikan kepada dirinya apabila perilakunya tidak sesuai dengan lingkungan sosial di tempatnya berada. Dampak dari adanya tekanan sosial dapat mempengaruhi pembuatan keputusan individu, seperti keputusan investasi, edukasi, pilihan politik (Bursztyn dan Jensen, 2017), kepatuhan dalam membayar pajak (Jimenez dan Iyer, 2016), termasuk keputusan etis. Apabila dikaitkan dengan kepatuhan wajib pajak, wajib pajak yang berada dalam lingkungan yang patuh membayar pajak akan berusaha mengikuti perilaku lingkungan sekitarnya untuk membayar pajak. Hal tersebut disebabkan adanya faktor ketakutan individu atas penilaian sosial yang dilakukan oleh lingkungan sekitarnya. Namun sebaliknya, wajib pajak yang berada dalam lingkungan yang tidak patuh membayar pajak cenderung mengikuti perilaku lingkungannya untuk tidak membayar pajak.

Kontrol perilaku yang dirasakan (perceived behavioral control) persepsi atas kemampuan individu untuk melakukan suatu perilaku (Novianti dan Dewi, 2018). Kontrol perilaku yang dirasakan juga dapat diartikan sebagai persepsi individu mengenai tingkat kemudahan suatu perilaku (Johe dan Bhullar, 2016). Apabila individu merasa percaya bahwa dirinya mampu melakukan suatu tindakan, maka persepsi tersebut 
dapat membentuk niat dalam diri individu, dan niat tersebut akan diwujudkan melalui perilaku nyata individu. Sebaliknya, apabila individu merasa bahwa suatu tindakan susah untuk dilakukan, maka tidak akan timbul niat untuk mewujudkannya secara nyata. Dengan kata lain, persepsi individu terhadap kemampuan untuk mengontrol suatu tindakan dapat mempengaruhi niat dan perilaku individu. Dalam konteks perpajakan, wajib pajak tidak patuh membayar pajak karena adanya rasa percaya diri bahwa dirinya bisa dengan mudah untuk menghindari pajak. Hal tersebut dapat disebabkan salah satunya oleh lemahnya pengawasan dan proses hukum perpajakan yang dilakukan oleh otoritas pajak (Yasa dan Martadinata, 2019). Sebaliknya, kuatnya pengawasan dan proses hukum perpajakan dapat mempersulit penghindaran pajak, sehingga memaksa wajib pajak untuk patuh membayar pajak (Yasa dan Martadinata, 2019).

Hasil penelitian López-Mosquera (2016) dan Marandu et al. (2015) menunjukkan bahwa perceived behavioral control dapat mempengaruhi perilaku kepatuhan, yang ditunjukkan dalam Gambar 2. Garis putusputus yang menghubungkan antara kontrol perilaku yang dirasakan wajib pajak dengan perilaku membayar pajak menunjukkan bahwa perceived behavioral control dapat mempengaruhi perilaku individu secara langsung, sesuai dengan hasil penelitian López-Mosquera (2016) dan Marandu et al. (2015). Hal tersebut mendasari penelitian ini untuk menggunakan perceived behavioral control sebagai variabel utama dalam TPB yang memprediksi perilaku kepatuhan wajib pajak.

\section{Pengembangan Hipotesis}

Beberapa penelitian telah menguji hubungan penerapan Tri Kaya Parisudha terhadap perilaku individu. Swardhana et al. (2015) menemukan bahwa nilai kearifan lokal Bali, dalam hal ini adalah Tri Kaya Parisudha dapat diimplementasikan sebagai kontrol sosial masyarakat untuk menang- gulangi perilaku kenakalan remaja. Selain itu, Kepramareni et al. (2014) menemukan bahwa penerapan konsep Tri Kaya Parisudha mendorong akuntabilitas pada pengeloloaan suatu organisasi nirlaba. Selain itu, Dewi (2019) melakukan penelitian terhadap perilaku etis auditor, dan menemukan bahwa Tri Kaya Parisudha mampu meningkatkan sensitifitas etika auditor.

Dalam aspek pendidikan, Prayudi dan Martadinata (2018) menemukan bahwa pengimplementasian nilai Tri Kaya Parisudha dalam pendidikan etika bisnis mampu meningkatkan penalaran moral mahasiswa dalam menghadapi kasus dilema etika. Sedangkan dalam konteks perpajakan, Yasa dan Prayudi (2017) melakukan penelitian yang menguji peran nilai etika berbasis kearifan lokal, dalam hal ini adalah Tri Kaya Parisudha, terhadap kepatuhan perpajakan pada 400 wajib pajak orang pribadi di Bali. Hasi penelitian Yasa dan Prayudi (2017) menunjukkan bahwa penyucian terhadap tiga unsur dalam perilaku, yaitu pikiran (manacika), perbuatan (kayika) dan perkataan (wacika) dapat mempengaruhi niat seseorang untuk patuh membayar pajak.

Dari hasil beberapa penelitian terdahulu, dapat disimpulkan bahwa penyucian dan pengendalian pikiran (manacika), perbuatan (kayika) dan perkataan (wacika) merupakan hal yang sangat penting dalam membentuk perilaku etis individu. Hal tersebut disebabkan oleh konsep Tri Kaya Parisudha yang berusaha menuntun manusia untuk berperilaku sesuai dengan ajaran kebenaran atau dharma. Maka dari itu, Tri Kaya Parisudha dapat menjadi pedoman etika bagi manusia secara universal.

Berhubungan dengan konsep TPB, beberapa penelitian telah menguji pengaruh kontrol perilaku yang dirasakan (perceived behavioral control) terhadap perilaku kepatuhan individu terhadap perilaku tertentu. López-Mosquera (2016) dalam penelitiannya menguji keterkaitan antara gender, TPB dan kepatuhan masyarakat untuk menyumbangkan uangnya demi kegiatan konservasi alam di Spanyol. Dalam 
penelitiannya, López-Mosquera (2016) menemukan bahwa di antara tiga unsur TPB, norma sosial dan kontrol perilaku yang dirasakan merupakan prediktor yang sangat kuat dalam mendorong kemauan masyarakat untuk menyumbangkan uangnya. Selain itu, konsisten dengan hasil penelitian López-Mosquera (2016), Marandu et al. (2015) melakukan studi literatur untuk mengkaji faktor-faktor yang mempengaruhi kepatuhan wajib pajak berdasarkan TPB. Pada variabel perceived behavioral control, Marandu et al. (2015) menggunakan beberapa proksi yang dapat membentuk persepsi kemampuan individu yang berkaitan dengan perilaku pajak. Berdasarkan hasil penelitian Marandu et al. (2015), ditemukan bahwa beberapa proksi seperti sanksi hukum, kemungkinan diaudit, peran otoritas pajak, hukum pajak, tingkat korupsi negara, sistem informasi perpajakan, efektivitas hukum, dan kompetensi otoritas penyelenggara pajak dapat mempengaruhi kepatuhan wajib pajak. Sedangkan Alleyne dan Harris (2017) menemukan bahwa perceived behavioral control yang diproksikan melalui rasa takut atas pengenaan hukuman terhadap pelanggaran pajak dapat mengurangi perilaku penghindaran pajak.

Secara keseluruhan, hasil penelitian López-Mosquera (2016) Marandu et al. (2015), dan Alleyne dan Harris (2017) memperkuat dugaan bahwa kontrol perilaku yang dirasakan merupakan komponen yang sangat penting dalam menjelaskan perilaku kepatuhan wajib pajak. Apabila wajib pajak merasa bahwa melanggar pajak merupakan hal yang mudah, maka wajib pajak memiliki potensi yang tinggi untuk melanggar pajak. Namun, diduga tidak semua wajib pajak akan terjerumus untuk melakukan pelanggaran perpajakan. Tri Kaya Parisudha merupakan salah satu aspek dalam diri yang dapat mengendalikan perilaku individu, sehingga tingkat Tri Kaya Parisudha dalam diri wajib pajak dapat mempengaruhi pengambilan keputusan perpajakan di kondisi tertentu. Pada kondisi wajib pajak memiliki perceived behavioral control yang tinggi (me- rasa mudah untuk melanggar pajak), individu dengan tingkat Tri Kaya Parisudha dalam diri yang tinggi tidak terjerumus untuk melakukan pelanggaran pajak. Hal tersebut disebabkan oleh adanya kontrol perilaku dalam diri individu untuk tidak melakukan perbuatan yang tergolong tidak baik atau suci, dalam hal ini adalah melanggar pajak, meskipun lingkungan sekitarnya mendukung untuk melakukan pelanggaran pajak. Sebaliknya individu dengan tingkat Tri Kaya Parisudha dalam diri yang rendah akan mudah terjerumus untuk melakukan pelanggaran pajak, sebagai akibat dari kontrol diri yang rendah, serta adanya kesempatan untuk melanggar pajak demi keuntungan pribadi.

Perilaku yang berbeda diduga terjadi pada kondisi wajib pajak memiliki perceived behavioral control yang rendah (merasa sulit untuk melanggar pajak), terutama pada individu dengan tingkat Tri Kaya Parisudha dalam diri yang rendah. Meskipun terdapat niat untuk melanggar, namun pengawasan yang ketat dan hukuman yang tegas akan menyebabkan kekhawatiran dalam diri wajib pajak untuk melanggar pajak sehingga memaksa wajib pajak untuk patuh membayar pajak. Sedangkan wajib pajak dengan tingkat Tri Kaya Parisudha dalam diri yang tinggi akan tetap patuh membayar pajak, karena pada dasarnya kontrol terhadap pikiran, perkataan dan perbuatan yang tercermin dalam Tri Kaya Parisudha merupakan aspek penting yang dapat menekan perilaku tidak etis individu tanpa dipengaruhi oleh kondisi perceived behavioral control. Berdasarkan kerangka pemikiran yang telah diuraikan, maka hipotesis yang diajukan adalah:

$\mathrm{H}_{1}$ : Pada kondisi perceived behavioral control yang tinggi, wajib pajak dengan Tri Kaya Parisudha yang tinggi menunjukkan tingkat kepatuhan yang lebih tinggi dibandingkan dengan wajib pajak dengan Tri Kaya Parisudha yang rendah.

$\mathrm{H}_{2}$ : Pada kondisi perceived behavioral control yang rendah, tidak terdapat 
perbedaan tingkat kepatuhan antara wajib pajak dengan Tri Kaya Parisudha yang tinggi dan wajib pajak dengan Tri Kaya Parisudha yang rendah.

$\mathrm{H}_{3}$ : Wajib pajak dengan Tri Kaya Parisudha yang rendah menunjukkan tingkat kepatuhan yang lebih rendah pada kondisi perceived behavioral control yang tinggi dibandingkan dengan kondisi perceived behavioral control yang rendah.

$\mathrm{H}_{4}$ : Tidak terdapat perbedaan tingkat kepatuhan pada wajib pajak dengan Tri Kaya Parisudha yang tinggi pada kondisi perceived behavioral control yang tinggi dan kondisi perceived behavioral control yang rendah.

\section{METODE PENELITIAN}

Desain Eksperimen

Pengujian hipotesis pada penelitian ini menggunakan metode eksperimen dengan desain 2x1 antar subyek (between subject design). Kontrol perilaku yang dirasakan (perceived behavioral control-PBC) digunakan sebagai perlakuan (treatment) dalam eksperimen (PBC tinggi dan PBC rendah), sedangkan Tri Kaya Parisudha (TKP) diukur pada masing-masing partisipan. Kriteria partisipan eksperimen adalah individu yang berstatus Wajib Pajak Orang Pribadi (WPOP) yang telah terdaftar pada Kantor Pelayanan Pajak (KPP) di Bali. Partisipan eksperimen dipilih secara acak. Terdapat empat kelompok eksperimen yang dibagi berdasarkan variabel yang digunakan dalam pe= nelitian ini. Desain eksperimen penelitian ini digambarkan pada Tabel 1.

Partisipan yang memperoleh perlakuan "Kontrol Perilaku yang Dirasakan Tinggi" akan dikelompokkan ke dalam Kelompok A dan C. Sedangkan partisipan yang memperoleh perlakuan "Kontrol Perilaku yang Dirasakan Rendah" akan dikelompokkan ke dalam Kelompok B dan D.

Tabel 1

Desain Eksperimen

\begin{tabular}{ccc}
\hline & \multicolumn{2}{c}{$\begin{array}{c}\text { Kontrol Perilaku yang Dirasakan } \\
\text { (Perceived Behavioral Control-PBC) }\end{array}$} \\
\hline Tri Kaya Parisudha (TKP) & Tinggi & Rendah \\
\hline Tinggi & $\mathrm{A}$ & $\mathrm{B}$ \\
Rendah & $\mathrm{C}$ & $\mathrm{D}$ \\
\hline
\end{tabular}

Pengelompokan selanjutnya dilakukan berdasarkan tingkat Tri Kaya Parisudha (TKP) dari masing-masing partisipan. Pengelompokan ke tahap selanjutnya dilakukan setelah data seluruh partisipan terkumpul untuk menentukan kategori tingkat Tri Kaya Parisudha partisipan. Partisipan yang memperoleh perlakuan "Kontrol Perilaku yang Dirasakan Tinggi" dan memiliki Tri Kaya Parisudha yang tinggi akan dikelompokkan ke dalam Kelompok A. Partisipan yang memperoleh perlakuan "Kontrol Perilaku yang Dirasakan Tinggi" dan memiliki Tri Kaya Parisudha yang rendah akan dikelompokkan ke dalam Kelompok C. Partisipan yang memperoleh perlakuan "Kontrol
Perilaku yang Dirasakan Rendah" dan memiliki Tri Kaya Parisudha yang tinggi akan dikelompokkan ke dalam Kelompok B. Sedangkan partisipan yang memperoleh perlakuan "Kontrol Perilaku yang Dirasakan Rendah" dan memiliki Tri Kaya Parisudha yang rendah akan dikelompokkan ke dalam Kelompok D.

\section{Teknik Pengumpulan Data}

Pengumpulan data dilakukan dengan menyebarkan instrumen penelitian kepada masing-masing partisipan eksperimen di dalam suatu lab eksperimen. Berikut merupakan gambaran terperinci mengenai metode pengumpulan data penelitian ini: 
1. Instrumen berupa kuesioner dibagikan kepada para partisipan.

2. Partisipan diarahkan untuk mengisi data demografi, membaca materi kasus, dan diminta untuk memberikan respon terhadap kasus yang diberikan serta menjawab pertanyaan manipulation check.

3. Partisipan diminta untuk mengisi respon terhadap pernyataan yang mengukur Tri Kaya Parisudha.

\section{Definisi Operasional dan Pengukuran Variabel}

Variabel independen dalam penelitian ini adalah Tri Kaya Parisudha dan kontrol perilaku yang dirasakan (perceived behavioral control). Sedangkan variabel dependen penelitian ini adalah kepatuhan wajib pajak. Tri Kaya Parisudha merupakan tiga perbuatan atau tingkah laku yang harus disucikan (Rosalina, 2017). Tingkat pengendalian pikiran (manacika), perbuatan (kayika) dan perkataan (wacika) dalam konsep Tri Kaya Parisudha diukur dengan menggunakan kuesioner yang dikembangkan oleh Yasa dan Prayudi (2017). Partisipan akan dikelompokkan ke dalam dua kelompok berdasarkan tingkat Tri Kaya Parisudha (TKP) yang dimiliki, yaitu TKP Tinggi dan TKP Rendah. Pengelompokkan dilakukan melalui metode median split, yaitu membagi partisipan berdasarkan median dari data skor TKP seluruh partisipan. Median split merupakan metode yang valid dan robust untuk digunakan dalam uji beda antar kelompok (Iacobucci et al., 2015).

Variabel kontrol perilaku yang dirasakan (perceived behavioral control) digunakan sebagai perlakuan dalam eksperimen. Eksperimen yang dilakukan dalam penelitian ini menggunakan skenario yang diadaptasi dari penelitian Yasa dan Martadinata (2019). Partisipan diminta untuk membayangkan dirinya sebagai pengusaha di sebuah negara fiktif dengan kondisi hukum perpajakan yang berbeda. Pada kondisi PBC Tinggi, negara fiktif tersebut tidak memiliki sistem penegakan hukum perpajakan yang optimal sehingga partisipan merasa me- miliki kontrol yang tinggi terhadap perilakunya untuk melanggar pajak (merasa mudah untuk melanggar pajak). Sebaliknya, pada kondisi PBC Rendah, negara fiktif tersebut memiliki sistem penegakan hukum perpajakan yang optimal sehingga partisipan merasa memiliki kontrol yang rendah terhadap perilakunya untuk melanggar pajak (merasa sulit untuk melanggar pajak).

Eksperimen ini menggunakan manipulation check untuk memastikan bahwa perlakuan (treatment) yang diberikan kepada partisipan berhasil. Manipulation check yang dilakukan adalah dengan meminta partisipan untuk memilih salah satu dari dua pernyataan yang mencerminkan treatment eksperimen, yaitu "Saya merasa mudah untuk melakukan pelanggaran pajak" atau "Saya merasa susah untuk melakukan pelanggaran pajak". Apabila partisipan memilih pernyataan yang sesuai dengan treatment yang diberikan, maka treatment diang gap berhasil dan data partisipan dapat dianalisis lebih lanjut. Untuk mengukur perilaku kepatuhan wajib pajak, partisipan diminta untuk melaporkan jumlah angka pendapatan yang diterima (dalam Rupiah) yang digunakan sebagai dasar pembayaran pajak. Semakin tinggi jumlah yang dilaporkan, maka semakin jujur partisipan untuk membayar pajak, dengan kata lain semakin tinggi tingkat kepatuhan wajib pajak.

\section{Teknik Analisis Data}

Pengujian hipotesis dilakukan dengan menggunakan metode two-way analysis of variance (ANOVA) untuk menguji interaksi antara Tri Kaya Parisudha dan kontrol perilaku yang dirasakan (perceived behavioral contol) dengan taraf signifikansi (a) sebesar 0,05 (5\%). Pengujian asumsi ANOVA dan hipotesis penelitian dilakukan dengan bantuan perangkat lunak Statistical Package for the Social Sciences (SPSS) versi 25.

\section{ANALISIS DAN PEMBAHASAN Deskripsi Data}

Eksperimen penelitian ini dilakukan pada 68 orang wajib pajak di wilayah kota 
Singaraja, Bali. Para wajib pajak diundang untuk menjadi partisipan eksperimen secara sukarela. Dari 68 data yang diperoleh dari partisipan, sebanyak 10 data dikeluarkan dari analisis data karena dideteksi sebagai outlier, sehingga data yang digunakan untuk analisis adalah berjumlah 58 data partisipan. Dari 58 partisipan, sebanyak 17 orang berjenis kelamin laki-laki $(29,30 \%)$ dan 42 orang berjenis kelamin perempuan $(70,70 \%)$. Partisipan rata-rata berusia 31 tahun. Dalam pelaksanaan eksperimen, partisipan dikelompokkan menjadi dua kelompok treatment berdasarkan perceived behavioral control (PBC) secara acak, yaitu PBC Tinggi dan PBC Rendah. Dari hasil analisi data, sebanyak 31 partisipan berada di kelompok PBC Tinggi, dan sebanyak 27 partisipan berada di kelompok PBC Rendah. Setelah dikelompokkan berdasarkan kelompok treatment, selanjutnya data dikelompokkan kembali berdasarkan tingkat Tri Kaya Parisudha (TKP) partisipan, yaitu TKP Tinggi dan TKP Rendah. Pengelompokan tersebut dilakukan berdasarkan median dari data skor TKP seluruh partisipan (median split). Berdasarkan hasil analisis data, median dari skor TKP partisipan adalah sebesar 70. Apabila jumlah skor TKP partisipan lebih besar dari skor median sebesar 70, maka partisipan dimasukkan ke dalam kelompok TKP Tinggi. Apabila jumlah skor TKP partisipan lebih kecil atau sama dengan skor median sebesar 70, maka partisipan dimasukkan ke dalam kelompok TKP Rendah.
Partisipan yang memperoleh perlakuan PBC Tinggi dengan tingkat TKP yang tinggi berjumlah 15 orang. Partisipan yang memperoleh perlakuan PBC Tinggi dengan tingkat TKP yang rendah berjumlah 16 orang. Untuk partisipan yang memperoleh perlakuan PBC Rendah dengan tingkat TKP yang tinggi berjumlah 14 orang. Sedangkan partisipan yang memperoleh perlakuan PBC Rendah dengan tingkat TKP yang rendah berjumlah 13 orang.

Setelah data partisipan dikelompokkan berdasarkan tingkat TKP dan treatment yang diterima, langkah selanjutnya adalah melakukan analisis terhadap jumlah pendapatan yang dilaporkan oleh partisipan pada masing-masing kelompok. Jumlah pendapatan yang dilaporkan merupakan ukuran yang digunakan untuk menentukan tingkat kepatuhan Wajib Pajak untuk memenuhi kewajibannya dalam membayar pajak. Dari hasil analisis yang telah dilakukan, ditemukan bahwa perilaku kepatuhan partisipan terlihat berbeda di antara kelompok dengan TKP dan treatment yang berbeda. Maka dari itu, dugaan awal atas data yang telah dikumpulkan adalah bahwa terdapat pengaruh dari kedua variabel yang diuji terhadap kepatuhan Wajib Pajak. Berikut merupakan tabel yang mendeskripsikan secara rinci mengenai pengelompokan data partisipan dan jumlah pendapatan yang dilaporkan oleh para partisipan dalam masing-masing kelompok:

Tabel 2

Data demografi

\begin{tabular}{llcc}
\hline & Keterangan & Jumlah & Persentase (\%) \\
\hline \multirow{2}{*}{ Jenis } & Laki-laki & 17 & 29,30 \\
Kelamin & Perempuan & 41 & 70,70 \\
\cline { 2 - 4 } & Total & 58 & 100,00 \\
\hline \multirow{4}{*}{ Umur } & 30 & 27 & 46,55 \\
& $30-40$ & 28 & 48,26 \\
& $>40$ & 3 & 5,19 \\
\cline { 2 - 4 } & Total & 58 & 100,00 \\
\hline
\end{tabular}

Sumber: data penelitian (2019) 
Tabel 3

Data partisipan berdasarkan kelompok treatment dan Tri Kaya Parisudha

\begin{tabular}{|c|c|c|c|c|}
\hline & \multicolumn{2}{|c|}{ Keterangan } & \multirow{2}{*}{$\begin{array}{c}\text { Jumlah Partisipan } \\
15\end{array}$} & \multirow{2}{*}{$\begin{array}{c}\begin{array}{c}\text { Rata-rata Jumlah } \\
\text { Pendapatan yang } \\
\text { Dilaporkan }\end{array} \\
\text { (dalam Rupiah) }\end{array}$} \\
\hline \multirow{4}{*}{$\begin{array}{l}\text { Kelompok } \\
\text { Perlakuan }\end{array}$} & PBC & TKP Tinggi & & \\
\hline & Tinggi & TKP Rendah & 16 & $93.750 .000,00$ \\
\hline & PBC & TKP Tinggi & 14 & $105.000 .000,00$ \\
\hline & Rendah & TKP Rendah & 13 & $104.615 .384,62$ \\
\hline
\end{tabular}

Sumber: data penelitian (2019)

Data Tabel 3 menunjukkan jumlah partisipan untuk masing-masing kelompok eksperimen dan rata-rata jumlah pendapatan yang dilaporkan. Kelompok PBC TinggiTKP Tinggi memiliki rata-rata jumlah pendapatan yang dilaporkan sebesar Rp 105.333.333,33. Jumlah tersebut merupakan jumlah tertinggi di antara kelompok eksperimen. Dengan kata lain, kelompok ini memiliki tingkat kepatuhan tertinggi dari segi jumlah pendapatan yang dilaporkan. Kelompok PBC Rendah-TKP Tinggi memiliki rata-rata jumlah pendapatan yang dilaporkan sebesar Rp 105.000,00 (terbesar kedua di antara kelompok eksperimen lainnya). Kelompok PBC Rendah-TKP Rendah memiliki rata-rata jumlah pendapatan yang dilaporkan sebesar Rp 104.615.384,62 (terbesar ke-tiga di antara kelompok eksperimen lainnya). Sedangkan kelompok PBC TinggiTKP Rendah menunjukkan rata-rata jumlah pendapatan yang dilaporkan paling rendah, yaitu sebesar Rp 93.750.000,00. Dengan kata lain, kelompok ini memiliki tingkat kepatuhan terendah dari segi jumlah pendapatan yang dilaporkan.

Berdasarkan hasil analisis lebih lanjut, dari 58 partisipan, sebanyak 30 partisipan melaporkan pendapatannya secara penuh (jujur). Dengan kata lain, jumlah pendapatan yang dilaporkan oleh partisipan sesuai dengan jumlah pendapatan yang sebenarnya. Sedangkan sisanya sebanyak 28 partisipan melaporkan jumlah pendapatannya secara tidak jujur. Pelaporan tidak jujur yang dimaksud adalah jumlah pendapatan yang dilaporkan oleh partisipan tidak sesuai dengan jumlah pendapatan sebenarnya.

Tabel 4

Data partisipan berdasarkan kejujuran pelaporan pendapatan

\begin{tabular}{ccccc}
\hline \hline Keterangan & & $\begin{array}{c}\text { Jumlah Partisipan yang } \\
\text { Melapor Secara Jujur }\end{array}$ & $\begin{array}{c}\text { Jumlah Partisipan } \\
\text { yang Melapor Secara } \\
\text { Tidak Jujur }\end{array}$ \\
\hline \multirow{3}{*}{$\begin{array}{c}\text { Kelompok } \\
\text { Perlakuan }\end{array}$} & PBC & TKP Tinggi & 10 & 5 \\
& Tinggi & TKP Rendah & 3 & 13 \\
\hline & PBC & TKP Tinggi & 9 & 5 \\
& Rendah & TKP Rendah & 8 & 5 \\
\hline
\end{tabular}

Sumber: data penelitian (2019)

Tabel 4 menunjukkan rincian jumlah partisipan yang melaporkan pendapatannya secara jujur berdasarkan kelompok treatment.
Dari Tabel 4, dapat dilihat bahwa jumlah partisipan yang melapor secara jujur sebagian besar merupakan partisipan yang 
memiliki Tri Kaya Parisudha yang tinggi (total 19 dari 30 partisipan yang melapor secara jujur). Pada kondisi PBC Tinggi (mudah untuk melanggar pajak), wajib pajak dengan TKP Tinggi menunjukkan tingkat kejujuran yang lebih tinggi (10 partisipan melaporkan pendapatannya secara jujur) dibandingkan dengan wajib pajak dengan TKP Rendah (3 partisipan melaporkan pendapatannya secara jujur). Sedangkan pada kondisi PBC Rendah (sulit untuk melanggar pajak), wajib pajak dengan TKP Tinggi menunjukkan tingkat kejujuran yang sedikit lebih tinggi (9 partisipan melaporkan pendapatannya secara jujur) dibandingkan dengan wajib pajak dengan TKP Rendah (8 partisipan melaporkan pendapatannya secara jujur). Peningkatan kejujuran terlihat pada wajib pajak dengan TKP Rendah pada kondisi PBC Rendah.

\section{Pengujian Hipotesis}

Sebelum melakukan uji hipotesis, terlebih dahulu dilakukan uji asumsi ANOVA yang terdiri dari uji normalitas dan homogenitas data. Berdasarkan hasil Levene's test pada Tabel 5, dapat dilihat bahwa data memiliki varians yang homogen dengan nilai Sig. lebih besar dari 0,05. Untuk uji normalitas, hasil analisis data menunjukkan bahwa data tidak normal. Asumsi normalitas data penelitian ini tidak terpenuhi sebagai akibat dari skewness (kecondongan) data respon partisipan. Namun, uji ANOVA tetap robust untuk dilakukan meskipun data tidak memenuhi asumsi normalitas, dengan syarat bahwa hal tersebut disebabkan oleh skewness dari distribusi data dan terbebas dari adanya outlier (Gudono, 2015). Maka dari itu, uji hipotesis menggunakan ANOVA tetap dapat dilakukan.

Tabel 5

Hasil uji homogenitas menggunakan Levene's test

\begin{tabular}{llcccc}
\hline \hline & Levene & & & \\
& & Statistic & df 1 & df 2 & Sig. \\
\hline Pajak & Based on Mean & 2.474 & 3 & 54 & .071 \\
& 1.854 & 3 & 54 & .148 \\
& Based on Median & 3 & 52.763 & .149 \\
Based on Median and with adjusted df & 1.854 & 5 & 54 & .071 \\
Based on trimmed mean & 2.478 & 3 &
\end{tabular}

Sumber: data penelitian (2019)

Tabel 6

Hasil Uji two-way ANOVA

\begin{tabular}{lrrrrr}
\hline \multicolumn{1}{c}{ Source } & $\begin{array}{c}\text { Type III Sum of } \\
\text { Squares }\end{array}$ & df & Mean Square & \multicolumn{1}{c}{$\boldsymbol{F}$} & \multicolumn{1}{c}{ Sig. } \\
\hline Corrected Model & $1469969053.935^{\mathrm{a}}$ & 3 & 489989684.645 & 5.984 & .001 \\
Intercept & 601886913452.549 & 1 & 601886913452.549 & 7351.024 & .000 \\
TKP & 516116554.347 & 1 & 516116554.347 & 6.303 & .015 \\
Treatment & 399700121.415 & 1 & 399700121.415 & 4.882 & .031 \\
TKP ${ }^{*}$ Treatment & 451902728.246 & 1 & 451902728.246 & 5.519 & .022 \\
Error & 4421410256.410 & 54 & 81877967.711 & & \\
Total & 608100000000.000 & 58 & & & \\
Corrected Total & 5891379310.345 & 57 & & & \\
\hline
\end{tabular}

a. $R$ Squared $=.250$ (Adjusted $R$ Squared $=.208$ )

Sumber: data penelitian (2019) 
Tabel 6 merupakan hasil analisis twoway ANOVA untuk menguji interaksi antara Tri Kaya Parisudha (TKP) dan treatment yang diberikan (perceived behavioral control). Dari Tabel 6 dapat dilihat bahwa terdapat main effect pada variabel Tri Kaya Parisudha dan treatment (perceived behavioral control) dengan nilai Sig. masing-masing sebesar 0,015 dan $0,031$ ( $p<0,05)$. Hal tersebut menunjukkan bahwa Tri Kaya Parisudha dan perceived behavioral control masing-masing memiliki pengaruh yang signifikan terhadap perilaku kepatuhan wajib pajak. Selain itu, interaksi antara TKP dan treatment menunjukkan hasil yang signifikan dengan nilai Sig. sebesar $0,022(\mathrm{p}<0,05)$, yang menunjukkan bahwa terdapat pengaruh kombinasian antara Tri Kaya Parisudha dan perceived behavioral control sehingga menyebabkan timbulnya perbedaan perilaku wajib pajak.

Tabel 7

Hasil Uji Post Hoc Tukey's HSD

\begin{tabular}{llrrr}
\hline \multirow{4}{*}{ (I) Group } & & \multicolumn{1}{c}{ Mean } & & \\
\hline PBC Tinggi-TKP Tinggi & (J) Group & $11583.33^{*}$ & 3252.062 & \multicolumn{1}{c}{ Sig. } \\
& PBC Tinggi-TKP Rendah & 333.33 & 3362.582 & .004 \\
& PBC Rendah-TKP Tinggi & 717.95 & 3428.824 & .900 \\
& PBC Rendah-TKP Rendah & $-11583.33^{*}$ & 3252.062 & .004 \\
\hline PBC Tinggi-TKP Rendah & PBC Tinggi-TKP Tinggi & $-11250.00^{*}$ & 3311.465 & .007 \\
& PBC Rendah-TKP Tinggi & $-10865.38^{*}$ & 3378.710 & .011 \\
\hline PBC Rendah-TKP Tinggi & PBC Rendah-TKP Rendah & -333.33 & 3362.582 & 1.000 \\
& PBC Tinggi-TKP Tinggi & $11250.00^{*}$ & 3311.465 & .007 \\
& PBC Tinggi-TKP Rendah & 384.62 & 3485.216 & 1.000 \\
\hline PBC Rendah-TKP & PBC Rendah-TKP Rendah & -717.95 & 3428.824 & .997 \\
Rendah & PBC Tinggi-TKP Tinggi & $10865.38^{*}$ & 3378.710 & .011 \\
& PBC Tinggi-TKP Rendah & -384.62 & 3485.216 & 1.000 \\
\hline
\end{tabular}

*. The mean difference is significant at the .05 level.

Sumber: data penelitian (2019)

Untuk menganalisis secara lebih mendalam mengenai pengaruh kombinasian antara Tri Kaya Parisudha dan perceived behavioral control, serta menguji signifikansi perbedaan kepatuhan wajib pajak, maka dilakukan uji post hoc Tukey's HSD. Hasil pengujian post hoc dapat dilihat pada Tabel 7. Berdasarkan data Tabel 7, dapat dilihat bahwa:

1. Pada kondisi perceived behavioral control yang tinggi, wajib pajak dengan Tri Kaya Parisudha yang tinggi menunjukkan tingkat kepatuhan yang lebih tinggi dibandingkan dengan wajib pajak dengan Tri Kaya Parisudha yang rendah. Hal tersebut dilihat dari perbedaan tingkat kepatuhan yang signifikan antara kelompok PBC Tinggi-TKP Tinggi (Rp 105.333.333,33) dan PBC Tinggi-TKP Ren- dah $(\operatorname{Rp} 93.750 .000,00)$ dengan nilai Sig. sebesar 0,004 ( $p<0,01)$, sehingga H1 terdukung.

2. Pada kondisi perceived behavioral control yang rendah, tidak terdapat perbedaan tingkat kepatuhan antara wajib pajak dengan Tri Kaya Parisudha yang tinggi dan wajib pajak dengan Tri Kaya Parisudha yang rendah. Hal tersebut dilihat dari perbedaan tingkat kepatuhan yang tidak signifikan antara kelompok PBC Rendah-TKP Tinggi (Rp 105.000.000,00) dan PBC Rendah-TKP Rendah (Rp 104.615.384,62) dengan nilai Sig. sebesar $1,000(p>0,05)$, sehingga $\mathrm{H} 2$ terdukung.

3. Wajib pajak dengan Tri Kaya Parisudha yang rendah menunjukkan tingkat kepatuhan yang lebih rendah pada kondisi perceived behavioral control yang tinggi 
dibandingkan dengan kondisi perceived behavioral control yang rendah. Hal tersebut dilihat dari perbedaan tingkat kepatuhan yang signifikan antara kelompok PBC Tinggi-TKP Rendah (Rp 93.750. 000,00) dan PBC Rendah-TKP Rendah (Rp 104.615.384,62) dengan nilai Sig. sebesar 0,011 ( $p<0,05$ ), sehingga H3 terdukung.

4. Tidak terdapat perbedaan tingkat kepatuhan pada wajib pajak dengan Tri Kaya Parisudha yang tinggi pada kondisi perceived behavioral control yang tinggi dan kondisi perceived behavioral control yang rendah. Hal tersebut dilihat dari perbedaan tingkat kepatuhan yang tidak signifikan antara kelompok PBC TinggiTKP Tinggi (Rp 105.333.333,33) dan PBC Rendah-TKP Tinggi (Rp 105.000.000,00) dengan nilai Sig. sebesar 1,000 ( $p>0,05)$, sehingga $\mathrm{H} 4$ terdukung.

\section{Pembahasan}

Merujuk pada teori perilaku terencana (theory of planned behavior-TPB) serta beberapa penelitian terdahulu, kontrol perilaku yang dirasakan (perceived behavioral control-PBC) merupakan komponen terpenting dalam memprediksi perilaku individu. Perceived behavioral control menyebabkan individu untuk berperilaku berdasarkan pertimbangan tingkat kemudahan untuk melaksanakan perilaku yang diniatkan. Dalam konteks perpajakan, perceived behavioral control dapat terbentuk karena lingkungan eksternal sekitar individu, seperti penerapan hukum perpajakan. Penerapan hukum perpajakan yang tegas dapat membangun persepsi bahwa melanggar pajak merupakan sesuatu yang sulit untuk dilakukan, sehingga akan meningkatkan kepatuhan wajib pajak untuk melanggar pajak. Sebaliknya, penerapan hukum perpajakan yang tidak optimal akan menurunkan kepatuhan wajib pajak, karena wajib pajak memiliki persepsi bahwa melanggar pajak merupakan sesuatu yang mudah untuk dilakukan.

Peran pemerintah merupakan hal yang sangat penting dalam membentuk perceived behavioral control wajib pajak untuk patuh membayar pajak, meskipun dalam beberapa kondisi, wajib pajak patuh dengan terpaksa. Penerapan hukum perpajakan yang ketat dapat memaksa individu yang sebelumnya berniat untuk melanggar pajak, namun karena faktor perceived behavioral control yang rendah, akan memaksa wajib pajak untuk patuh membayar pajak. Selain perceived behavioral control, faktor karakteristik pribadi dapat mempengaruhi perilaku kepatuhan wajib pajak, salah satunya adalah Tri Kaya Parisudha. Tri Kaya Parisudha selalu mengajarkan manusia untuk menyucikan pikiran (manacika), perkataan (wacika), dan perbuatan (kayika). Wajib pajak yang menjaga pikiran (manacika), perkataan (wacika), dan perbuatan (kayika) cenderung akan menghindari perilaku yang tergolong tidak etis dan melanggar ajaran kebenaran (dharma), yaitu melakukan pelanggaran pajak.

Penelitian ini menemukan bahwa wajib pajak dengan Tri Kaya Parisudha yang tinggi cenderung lebih jujur melaporkan pajaknya dibandingkan dengan wajib pajak dengan Tri Kaya Parisudha yang rendah. Hal tersebut disebabkan oleh penanaman nilai-nilai religius dalam individu yang dapat menyebabkan individu untuk cenderung menghindari perilaku yang menjurus pada pelanggaran etika maupun hukum. Beberapa studi telah menemukan bahwa religiusitas mempengaruhi perilaku etis individu, terutama dalam hal yang berkaitan dengan kepatuhan wajib pajak.

Benk et al. (2016) melakukan studi pada wajib pajak di Turki, dan menemukan bahwa tingkat religiusitas wajib pajak memiliki pengaruh yang positif terhadap kepatuhan wajib pajak, baik kepatuhan yang sifatnya sukarela maupun terpaksa. Damayanti (2018) menemukan bahwa unsur religiusitas memperkuat niat wajib pajak untuk patuh membayar pajak. Sedangkan Mohdali et al. (2017) menemukan bahwa religiusitas memperkuat kepatuhan sukarela wajib pajak. Beberapa penelitian lainnya seperti Nurunnabi (2018), Ansar et al. (2018), dan Pratama (2017) menemukan bahwa religiusitas dapat 
meminimalisir perilaku penghindaran pajak, dengan kata lain penanaman nilai-nilai agama dalam diri wajib pajak dapat meningkatkan kepatuhan wajib pajak untuk membayar pajak.

Berdasarkan beberapa penelitian sebelumnya mengenai religiusitas dan kepatuhan wajib pajak, dapat ditarik simpulan bahwa pemahaman dan penerapan nilainilai agama dapat mendorong kesadaran wajib pajak untuk membayar pajak. Pajak pada dasarnya digunakan salah satunya untuk membantu pelaksanaan program pembangunan negara. Maka dari itu, membayar pajak merupakan salah satu bentuk dari dharma negara, yaitu pemenuhan kewajiban warga negara untuk negaranya. Tri Kaya Parisudha merupakan nilai religius dan kearifan lokal masyarakat Bali yang menuntun manusia agar selalu berperilaku berdasarkan ajaran agama dengan mengendalikan pikiran, ucapan, dan perbuatan. Maka dari itu, penanaman konsep Tri Kaya Parisudha dapat meningkatkan kesadaran moral individu untuk menunaikan kewajibannya sebagai manusia, salah satunya mengamalkan dharma negara dengan patuh dalam membayar pajak.

Hasil penelitian ini menemukan bahwa perceived behavioral control dan Tri Kaya Parisudha memberi pengaruh kombinasian yang menyebabkan perbedaan perilaku kepatuhan wajib pajak. Ketika tidak terdapat penegakan hukum yang optimal, wajib pajak dengan Tri Kaya Parisudha yang rendah memanfaatkan kesempatan tersebut untuk melanggar pajak dengan melaporkan pendapatannya secara tidak jujur. Sebaliknya, melalui penerapan nilai-nilai religius dan pengendalian diri (dharma agama), wajib pajak dengan Tri Kaya Parisudha yang tinggi cenderung tidak terpengaruh oleh kesempatan tersebut dan tetap melaksanakan kewajibannya sebagai warga negara dengan melaporkan pendapatan secara lebih jujur (dharma negara). Hal tersebut dibuktikan dari pelaporan pendapatan yang secara rata-rata lebih tinggi dibandingkan dengan wajib pajak dengan Tri Kaya Parisudha yang rendah. Selain itu, jumlah wajib pajak yang melaporkan pendapatannya secara penuh lebih banyak ditemukan pada wajib pajak dengan Tri Kaya Parisudha yang tinggi dibandingkan dengan wajib pajak dengan Tri Kaya Parisudha yang rendah.

Perilaku yang berbeda ditunjukkan oleh wajib dengan Tri Kaya Parisudha yang rendah ketika terdapat penegakan hukum perpajakan yang optimal. Ketika terdapat persepsi bahwa melanggar pajak merupakan hal yang sulit untuk dilakukan, wajib pajak dengan Tri Kaya Parisudha yang rendah cenderung melaporkan pajaknya secara jujur. Selain itu, rata-rata jumlah pendapatan yang dilaporkan tidak memiliki perbedaan yang signifkan terhadap jumlah pendapatan yang dilaporkan oleh wajib dengan Tri Kaya Parisudha yang tinggi. Kepatuhan tersebut diduga bersifat terpaksa sebagai akibat dari adanya penegakan hukum perpajakan yang tegas, sehingga mampu meningkatkan jumlah wajib pajak yang melaporkan pendapatannya secara jujur. Namun, wajib pajak dengan Tri Kaya Parisudha yang tinggi tidak menunjukkan perilaku yang berbeda. Tidak ada perbedaan yang signifikan pada jumlah pendapatan yang dilaporkan dan jumlah wajib pajak yang melaporkan pendapatannya secara jujur, baik pada kondisi perceived behavioral control yang tinggi maupun perceived behavioral control yang rendah.

Hasil penelitian ini secara keseluruhan mengkonfirmasi peran penting dari perceived behavioral control dalam memprediksi perilaku individu, khususnya perilaku kepatuhan wajib pajak. Kepatuhan wajib pajak ditentukan dari persepsi tingkat kemudahan atau kesulitan dari perilaku yang akan dilakukannya secara nyata. Selain itu, penelitian ini juga mengkonfirmasi pentingnya pengamalan nilai-nilai religius dalam Tri Kaya Parisudha dalam mendorong wajib pajak untuk patuh membayar pajak.

\section{SIMPULAN, DAN KETERBATASAN Simpulan}

Secara keseluruhan, penelitian ini menyimpulkan bahwa perceived behavioral 
control dan nilai kearifan lokal Tri Kaya Parisudha memiliki pengaruh kombinasian yang membentuk perilaku kepatuhan wajib pajak.

Penerapan nilai Tri Kaya Parisudha melalui penyucian pikiran, perkataan dan perbuatan dapat mendorong kepatuhan wajib pajak dalam membayar pajak tanpa memandang kondisi hukum perpajakan di negaranya. Meskipun terdapat kesempatan untuk melakukan penghindaran pajak, namun nilai-nilai religiusitas, dalam hal ini adalah Tri Kaya Parisudha, mampu menekan timbulnya perilaku oportunis untuk menghindari pajak sehingga Wajib Pajak tetap patuh untuk membayar pajak.

Namun, hal tersebut bukan berarti bahwa suatu negara tidak membutuhkan hukum pajak dalam mengawasi perilaku Wajib Pajak. Penegakan hukum perpajakan yang optimal merupakan salah satu faktor pembentuk perceived behavioral control yang akan mendorong wajib pajak untuk patuh, terutama bagi wajib pajak yang memiliki kesadaran diri yang rendah untuk membayar pajak.

\section{Implikasi}

Secara keseluruhan, hasil penelitian ini mendukung perilaku patuh wajib pajak yang disebabkan oleh perceived behavioral control dalam TPB yang dikombinasikan dengan budaya etika lokal Tri Kaya Parisudha, sehingga penelitian ini memberikan kontribusi teoritis dalam menjelaskan perilaku kepatuhan wajib pajak berdasarkan Theory of Planned Behavior. Hasil penelitian dengan metode eksperimen ini diharapkan dapat memperkuat relevansi TPB dalam menjelaskan perilaku kepatuhan wajib pajak tanpa melupakan budaya lokal yang sudah ada dan melekat dalam kehidupan masayarakat kita.

Selain itu, hasil penelitian ini diharapkan dapat menjadi pertimbangan bagi otoritas pajak untuk meningkatkan ke percayaan wajib pajak terhadap otoritas pajak, karena sebetulnya wajib pajak memiliki pemikiran yang baik terhadap perilaku mereka untuk berbuat patuh sehingga hal ini perlu terus dijaga dan ditingkatkan yang awalnya berasal dari pemikiran mereka diikuti dengan perbuatan wajib pajak untuk berperilaku patuh.

\section{Keterbatasan}

Meskipun penelitian ini mendukung konsep yang diujikan, namun terdapat beberapa keterbatasan dalam penelitian ini. Adapun keterbatasan pertama penelitian ini adalah penggunaan metode eksperimen. Metode eksperimen dalam menguji perilaku wajib pajak belum mencerminkan kondisi pengambilan keputusan perpajakan yang sebenarnya, meskipun metode eksperimen tepat digunakan untuk menguji suatu teori. Selain itu, jumlah data partisipan eksperimen yang digunakan dalam penelitian ini adalah sebanyak 58 data. Jumlah tersebut kemungkinan kurang representatif untuk mewakili jumlah Wajib Pajak Orang Pribadi yang terdaftar di KPP Bali. Maka dari itu, diperlukan kehati-hatian dalam penggeneralisasian hasil penelitian ini.

Keterbatasan kedua adalah mengenai penggunaan Tri Kaya Parisudha (TKP). TKP merupakan konsep kearifan lokal yang menjadi pedoman untuk berperilaku pada masyarakat Bali, sehingga kemungkinan konsep ini tidak dapat digunakan untuk menjelaskan perilaku kepatuhan wajib pajak pada masyarakat yang memiliki budaya maupun kepercayaan yang berbeda. Penelitian selanjutnya diharapkan menggunakan aspek keperilakuan yang dapat diterapkan pada masyarakat secara universal.

Untuk keterbatasan ketiga, penelitian ini hanya menguji perceived behavioral control yang merupakan salah satu dari tiga unsur dalam Theory of Planned Behavior.

Penelitian selanjutnya diharapkan menguji dua unsur lainnya, yaitu attitudes toward behavior dan subjective norms. Selain itu, penelitian selanjutnya diharapkan menghubungkan antara niat dan perilaku wajib pajak, sehingga dapat memperkuat relevansi Theory of Planned Behavior dalam menjelaskan perilaku wajib pajak. 


\section{DAFTAR PUSTAKA}

Adnyana, Putu Budi dan Desak Made Citrawathi. 2017. Model Pendidikan Karakter Berbasis Tri Kaya Parisudha Terintegrasi Dalam Pembelajaran Di Sekolah Dasar. Seminar Nasional Riset Inovatif 2017 ISBN: 978-602-6428-11-0

Alleyne, P. dan Harris, T. 2017. Antecedents of Taxpayers' Intentions to Engage in Tax Evasion: Evidence from Barbados. Journal of Financial Reporting and Accounting 15(1): 2-21.

Badan Pusat Statistik. 2019. Realisasi Penerimaan Negara (Milyar Rupiah), diakses melalui $h t t p s: / / w w w . b p s . g o . i d$ tanggal 2 September 2019.

Benk, S., Budak, T., Yüzbaşı, B., and Mohdali, R. 2016. The Impact of Religiosity on Tax Compliance Among Turkish SelfEmployed Taxpayers. Religions, 7(4), 37.

Bursztyn, Leonardo, and Robert Jensen. 2017. Social Image and Economic Behavior in the Field: Identifying, Understanding, and Shaping Social Pressure. Annual Review of Economics 9: 131-153.

Damayanti, T. W. 2018. Tax Compliance: Between Intrinsic Religiosity and Extrinsic Religiosity. Journal of Economics, Business \& Accountancy Ventura (JEBAV) 21(1): 41-49.

Damayanti, T. W., Sutrisno, Subekti, Imam dan Baridwan, Zaki. 2015. Trust and Uncertainty Orientation: An Efforts to Create Tax Compliance in Social Psychology Framework. Procedia-Social and Behavioral Sciences 211(2015): 938-944.

Dewi, I. G. P. E. R. 2019. Filosofi Tri Kaya Parisudha Memoderasi Pengaruh Equity Sensitivity Dan Ethical Sensitivity Pada Perilaku Etis Auditor Badan Pemeriksa Keuangan Perwakilan Provinsi Bali. Jurnal Penjaminan Mutu 5(1): 43-56.

Direktorat Jenderal Pajak. 2019. Tax Ratio diakses melalui http://www.pajak.go.id tanggal 6 Februari 2019.

Widyani, A. A. D. 2015. Knowledge Management dalam Perspektif Tri Kaya Parisuda serta Pengaruhnya Terhadap
Kinerja Pengurus Koperasi. Jurnal Ilmu Manajemen (JUIMA), 5(2).

Gudono. 2015. Analisis Data Multivariat. Edisi 4. Yogyakarta: BPFE Yogyakarta.

Iacobucci, D., S. S. Posavac, F. R. Kardes, M. J. Schneider, dan D. L. Popovich. 2015. The Median Split: Robust, Refined, and Revived. Journal of Consumer Psychology 25(4): 690-704.

Jimenez, P. dan Iyer, G. S. 2016. Tax Compliance in a Social Setting: The Influence of Social Norms, Trust in Government, and Perceived Fairness on Taxpayer Compliance. Advances In Accounting 34: 17-26.

Johe, M. H. dan Bhullar, N. 2016. To Buy or Not to Buy: The Roles of Self-Identity, Attitudes, Perceived Behavioral Control and Norms in Organic Consumerism. Ecological Economics 128: 99-105.

Kautonen, T., M. van Gelderen, dan M. Fink. 2015. Robustness of the Theory of Planned Behavior in Predicting Entrepreneurial Intentions and Actions. Entrepreneurship Theory and Practice 39(3): 655-674.)

Kementerian Keuangan Republik Indonesia. 2019. Postur APBN 2019 diakses melalui https://www.kemenkeu.go.id tanggal 6 Februari 2019.

Kepramareni, P., M. Sudarma, G. Irianto, dan A. F. Rahman. 2014. Sekala and Niskala Accountability Practices in the ClanBased Organization MGPSSR in Bali, Indonesia. Scientific Research Journal 2(2): 1-5.

Kiriana, Nyoman I. 2017. Implementasi Pendidikan Karakter sebagai Dharma Agama dan Dharma Negara. Jurnal Ilmu Agama 2: 64-73.

López-Mosquera, Natalia. 2016. Gender Differences, Theory of Planned Behavior and Willingness to Pay. Journal of Environmental Psychology 45: 165-175.

Manawa Dharmasastra. 2012. Ed. Gede Pudja dan Tjokorda Rai Sudharta. Denpasar: Widya Dharma.

Marandu, Edward E., Christian J. Mbekomize, and Alexander N. Ifezue. 2015. 
Determinants of Tax Compliance: A Review of Factors and Conceptualizations. International Journal of Economics and Finance 7(9): 207-218.

Mohdali, R., S. Benk, T. Budak, K. MohdIsa, and S. H. Yussof. 2017. A cross-cultural study of religiosity and tax compliance attitudes in Malaysia and Turkey. eJTR 15: 490.

Novianti, A. F., dan N. H. U. Dewi. 2018. An investigation of the Theory of Planned Behavior and the role of Tax Amnesty in tax compliance. The Indonesian Accounting Review (TIAR) 7(1): 79-94.

Nurunnabi, M. 2018. Tax Evasion and Religiosity in The Muslim World: The Significance of Shariah Regulation. Quality \& Quantity 52(1): 371-394.

Nurwanah, A., T. Sutrisno, R. Rosidi, dan R. Roekhudin. 2018. Determinants of Tax Compliance: Theory of Planned Behavior and Stakeholder Theory Perspective. Problems and Perspectives in Management 16(4).

Oktaviani, R. M. dan I. Nurhayati. 2015. Determinant Of Tax Compliace With Intention As Mediation From Planned Behaviour Theory Perspective. Prosiding Seminar Nasonal dan Call For Papers 2015. Fakultas Ekonomika Dan Bisnis Uni versitas 17 Agustus 1945 Semarang: 162-175

Onu, D. dan Oats, L. 2015. The Role of Social Norms in Tax Compliance: Theoretical Overview and Practical Implications. Journal of Tax Administration 1(1): 113137.

Pratama, A. 2017. Machiavellianism, Perception on Tax Administration, Religiosity and Love of Money Towards Tax Compliance: Exploratory Survey on Individual Taxpayers in Bandung City, Indonesia. International Journal of Economics and Business Research 14(3-4): 356370.

Prayudi, M. A., dan I. P. H. Martadinata. 2018. Tri Kaya Parisudha as A Cultural and Religious-Based Ethics Concept in Improving Accounting Student's Moral Judgment. $4^{\text {th }}$ International Conference on Accounting and Finance. Paper dipresentasikan di $4^{\text {th }}$ ICAF UMY, Universitas Muhammadiyah Yogyakarta, 25-26 April 2018.

Putri, N. E. dan Z. Fanani. 2018. Strategi Mempertahankan Harta Anak Bangsa Pasca Tax Amnesty. Media Riset Akuntansi, Auditing dan Informasi 18(1): 101-114.

Redaksi Ortax. 2019. Realisasi Sementara APBN 2018 diakses melalui https://www/ ortax.org.id tanggal 6 Februari 2019.

Rosalina, P. D. 2017. The Implementation of Hindu Philosophy "Tri Kaya Parisudha" for Sustainable Tourism in Munduk Village, North Bali. Jurnal Master Pariwisata (JUMPA).

Sarasamuscaya. 2016. Ed. I Made Yuda Asmara, S.Pd.H., M.Pd., diakses melalui www.issuu.com tanggal 18 Oktober 2016.

Swardhana, G. M., I. B. S. D. Jaya, dan I. G. A. P. Kartika. 2015. Kebijakan Kriminal dalam Penanggulangan Tindak Pidana dan Kenakalan Siswa SMA: Suatu Kajian tentang Penerapan Teori Kontrol Sosial dan Kearifan Lokal di Bali. Jurnal Magister Hukum Udayana 4(1): 28-47

Yasa, I. N. P. dan M. A. Prayudi. 2017. Perilaku Kepatuhan Perpajakan dalam Perspektif Teori Perilaku Terencana. Prosiding Seminar Nasional Riset Inovatif V 2017: 247-252

-----.2017. Pengujian Peran Nilai-Nilai Etika Berbasis Kearifan Lokal pada Kepatuhan Perpajakan dalam Perspektif Teori Perilaku Terencana. Tidak dipublikasikan. Yasa, I. N. P., dan I. P. H. Martadinata. 2019. Taxpayer Compliance from the Perspective of Slippery Slope Theory: An Experimental Study. Jurnal Akuntansi dan Keuangan 20(2): 53-61. 